\section{Chelonine (Hymenoptera: Braconidae: Cheloninae) Parasitoids of Lepidopteran Leafminers in the Indian Subcontinent, with Notes on Taxonomic Character}

Zubair Ahmad 1, 2, 5, Hamed A. Ghramhi, 2, 3, Khalid Ali Khan1, 2,3*, Kavita Pandey ${ }^{4}$ and Farhat Khan ${ }^{5}$

${ }^{1}$ Research Centre for Advanced Materials Science (RCAMS), King Khalid University, P.O. Box 9004, Abha 61413, Saudi Arabia

${ }^{2}$ Unit of Bee Research and Honey Production, Faculty of Science, King Khalid

University, P.O. Box 9004, Abha 61413, Saudi Arabia

${ }^{3}$ Biology Department, Faculty of Science, King Khalid University, P.O. Box 9004, Abha 61413, Saudi Arabia

${ }^{4}$ Department of Zoology, Aligarh Muslim University, Aligarh, 202002, UP-India

${ }^{5}$ Biology Department, Faculty of Sciences and Arts, King Khalid University, Dhahran Al

Janoub, Saudi Arabia

\begin{abstract}
A B S T R A C T
Two new species viz., Chelonus (Areselonus) caeruleus sp. nov. and Chelonus (Areselonus) lithocolletiscus, sp. nov., are described as new to science from the northern part of India. These two species were reared from Acrocercops caerulea (Meyrick) and Lithocolletis virgulata (Lepidoptera: Gracillariidae). Materials about other species viz., Ascogaster acrocercophagus Shujauddin and Varshney and C. (A.) chailini (Walker and Huddleston) have also been recorded. The importance of apico-dorsal spine of metasoma for taxonomy is discussed. An updated checklist of chelonine leafminer parasitoids from the Indian subcontinent is also provided.
\end{abstract}

\author{
Article Information \\ Received 04 December 2019 \\ Revised 02 January 2020 \\ Accepted 14 January 2020 \\ Available online 04 September 2020 \\ Authors' Contribution \\ ZA conceived the idea of the project. \\ ZA and KP carried out the sampling. \\ analysed the data and wrote the \\ manuscript. KAK contributed in final \\ preparation of the manuscript. HAG, \\ KAK and FK provided suggestions \\ and corrections. \\ Key words \\ Hymenoptera: Braconidae: \\ Cheloninae, Parasitoids, leafminers, \\ India, Pakistan
}

\section{INTRODUCTION}

$\mathrm{L}$ eaf mining insects are considered as serious pests, which damage plant leaves in several ways (Spencer, 1990). The majority of the leaf mining larvae belong to the Lepidoptera, followed to a lesser degree by Diptera, Coleoptera and Hymenoptera (Csoka, 2003). Among the lepidopteran leafminers the family Gracillariidae includes small-sized moths with white marks on the wings. Several species are considered severe pests in various parts of the world (Davis, 1987). Parasitoid insects play the most important role as the natural enemies of leaf miners. In some cases, they cause more than $90 \%$ mortality and have great potential in biological pest control programs (Hawkins et al., 1993). Parasitoids of leaf miners are exclusively from the order Hymenoptera. Among the parasitic Hymenoptera chalcids (Chalcidoidea) and Ichneumonidae and Braconidae (Ichneumonoidea) are the most important group associated with leaf miners.

\footnotetext{
* Corresponding author: khalidtalpur@hotmail.com 0030-9923/2020/0006-2209 \$ 9.00/0

Copyright 2020 Zoological Society of Pakistan
}

As far as Indian subcontinent is concerned, there is lack of information on braconid parasitoids especially reared from leaf-mining Lepidopteran hosts. So far only two species of chelonine parasitoids associated with lepidopteran leafminers described from India (Shujauddin and Varshney, 1997; Ahmad and Gharamh, 2018).

The chelonine parasitoids belong to the subfamily Cheloninae of braconid wasps with approximately 1400 described species in 17 genera worldwide (Yu et al., 2012; Kittel and Austin, 2014). All chelonines are believed to be solitary koinobiont endoparasitoids especially of larval Lepidoptera (Shaw and Huddlston, 1991). Kittel et al., 2016 in their comprehensive phylogenetic analysis of chelonine wasps treated Microchelonus Szépligeti as junior synonyms of Chelonus Jurine and also synonymised several subgenera of Microchelonus like Baculonus Braet and van Achterberg, Carinichelonus Tobias and Scabrichelonus He, Chen and van Achterberg. However, they did not comment on the status of subgenera of other Microchelonus (Areselonus, Megachelonus, Parachelonus, Rasnichelonus, and Stylochelonus). The subgenus Areselonus of the genus Chelonus Jurine was named by Braet (1999) to accommodate a species in which 
the carapace ends in an apical spine-like protuberance and vein SR1 of the fore wing is reduced. Huddleston and Walker (1994) as well as Braet (1999) consider the presence of dorso-apical spine is a distinct lineage within the genus Chelonus. This aberrant character was also found in Ascogaster sp. (Braet, 1999). Here in the present work, we also found the same character in Ascogaster acrocercophagus Shujauddin and Varshney. Apart from this the same character is also observed in Chelonus (Aresolenus) caeruleus sp. nov., which shares similarities with subgenus Chelonus s.str. (Antennae of female more than 16 flagellomere). Chelonus (Areselonus) chailini (Walker and Huddleston, 1987); Chelonus (Areselonus) pongamiae, sp. nov and Chelonus (Areselonus) spinigaster Ahmad and Gharamh, 2018 have similarities with subgenus Microchelonus s. str. (Antenna of female with 16 segments). Hence, all Indian chelonine species reared from leafminers possess this characteristic which includes genera Ascogaster, Chelonus s. str. Microchelonus s. str. Thus, the presence of this character has some association with leaf-mining behaviour rather than considering it as a separate lineage. Walker and Huddlston (1987) suggested the function of the dorso-apical spine is to use as an anchor or as a lever to give an extra push to the newly emerged adults in making their way out of the host cocoon. Therefore, the separate identity of subgenus Areselonus is uncertain. Further comprehensive studies of both morphological and molecular analysis will reveal the clear position of this group. At present, the authors are not able to make any taxonomic change to the status of subgenus Areselonus due to unavailability of type material. This subgenus contains only five described species (Yu et al., 2012; Ahmad and Gharamh, 2018; Long et al., 2019).

The objective of this study is to describe and illustrate two new species viz., Chelonus (Areselonus) caeruleus and Chelonus (Areselonus) lithocolletiscus, sp. nov., from Acrocercops caerulea (Meyrick) and Lithocolletis virgulata (Lepidoptera: Gracillariidae), respectively on their natural host plant Dolichos lablab, Pongamia glabra and Terminalia bellerica. An updated checklist of chelonine leaf-miner parasitoids from the Indian subcontinent is also provided in this paper (Table I).

\section{MATERIALS AND METHODS}

This study was conducted in the vicinity of western Uttar Pradesh (North India) to identify parasitoids of leaf miners along the roadside at AMU university campus. The parasitoids were reared in the laboratory in glass jars of 8 " $\times 4$ " in size in the insectory at $25^{\circ} \pm 2^{\circ} \mathrm{C}$ with $70 \%$ R.H. The leaves with lepidopteran leaf miners were collected from the plants and transferred to the rearing jars of 8 " $\times 4$ ". A complete data set such as the date of collection, locality, and name of host plant was maintained. The emerged parasitoids were preserved initially in $75 \%$ alcohol with a few drops of glycerol. These specimens were later mounted on cards. The reared parasitoids were separated based on morphological characters. Photos of body profile were taken by a Nikon SMZ 1000 stereo zoom microscope with attached camera. Measurements of the different parts were made with the help of an ocular micrometer fitted in Nikon SMZ stereomicroscope. We have followed van Achterberg (1993) for the terminologies of various body parts and wing venation and Eady (1968) for the terminology of micro-sculpture. The specimens were deposited in the Insect Collection of the Department of Zoology, Aligarh Muslim University, Aligarh, India (ZDAMU).

\section{Ascogaster acrocercophagus Shujauddin and Varshney}

Ascogaster acrocercophagus Shujauddin and Varshney, 1997: 95-97. ‥ India, Uttar Pradesh (ZDAMU).

\section{Diagnosis}

Antennae 35-39 segmented, scape more than $3.0 \times$ as long as broad, forewing vein 3-SR longer than vein $r$ and hind tibia $3.5 \times$ as long wide.

Table I. Updated checklist of Chelonini (Hym., Braconidae) parasitoids of leaf-miner from Indian subcontinent.

\begin{tabular}{lll}
\hline Species & Reference & Distribution \\
\hline Ascogaster acrocercophagus Shujauddin and Varshney & Shujauddin and Varshney (1997); Ahmad et al. & India \\
& (2018); Present study & Pakistan \\
Ascogaster quadridentata Wesmael & Bellows and Fisher (1999) & India \\
Chelonus (Areselonus) caeruleus Ahmad and Pandey, sp. nov. & Present study & Walker and Huddleston (1987); Braet (1999); India \\
Chelonus (Areselonus) chailini (Walker and Huddleston) & Present study & India \\
Chelonus (Areselonus) pongamiae Ahmad and Pandey, sp. nov. & Present study & Ahmad and Gharmh (2018) \\
Chelonus (Areselonus) spinigaster Ahmad and Ghramh & & India \\
\hline
\end{tabular}




\section{Material examined}

2웅, $8 \hat{\jmath}$, India: Uttar Pradesh, Bulandshahr; 11. xi. 2007; ex. Acrocercops syngramma Meyrick on Mangifera indica L., (coll. Zubair Ahmad); 5ㅇ, 7ð̂̋, India; Uttar Pradesh, Bijnor, 1.vii.2013, ex. Acrocercops phaeospora Meyrick (coll. Zubair Ahmad) (ZDAMU);

\section{Host}

Acrocercops syngramma Meyrick.

\section{Distribution}

India: Uttar Pradesh.

\section{Chelonus (Areselonus) caeruleus, Ahmad and Pandey sp. nov.}

(Fig. 1)

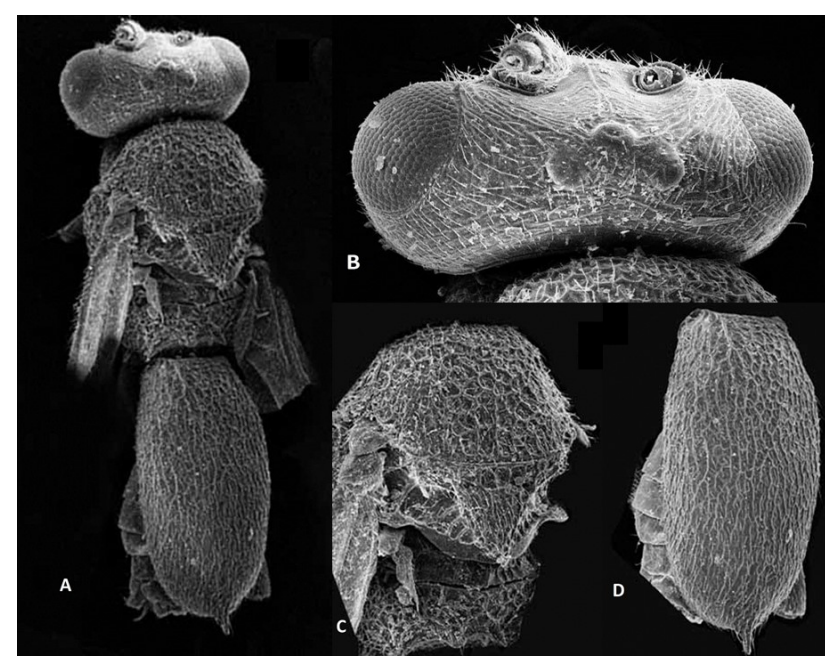

Fig. 1. Chelonus (Areselonus) caeruleus sp. nov., female, holotype; A, Habitus, dorsal aspect; B, Head dorsal aspect; C, Mesosoma dorsal View; D, Metasoma dorsal view.

\section{Material examined}

Holotype: q, INDIA: Uttar Pradesh, Aligarh, 26.10.68, ex Acrocercops caerulea (Meyrick) on Dolichos lablab (coll. Shujauddin) (ZDAMU). Paratype, 1 , , with same data as holotype (ZDAMU).

\section{Diagnosis}

Chelonus (Areselonus) caeruleus differs from all known Aresolenus group of species by antennae of a female with more than 16 segments; metasoma in lateral view 2.0-2.3 $\times$ as long as high, about twice as higher behind than at base i.e. distinctly increasing in height posteriorly, scutellar sulcus with five mid-longitudinal carinae. If the new species consider near to the subgenus Chelonus s.str., then $C$. (A.) caeruleus sp. nov., is closely related to $C$. $(C$.) gastrus Narendran et al. (1990) but differs in the following characters: (i). Scutellum pubescent rugoso-reticutate (scutellum shiny, pubescent rugose and strigose) (ii). Hind coxa smooth and hairy, $2.0 \times$ as long as wide (hind coxa rugose, $1.6 \times$ as long as wide) (iii). 3 -SR $2.7 \times$ as long as r (5: 3) (3-SR about as long as $1.2 \times$ r (6: 5) (iv). Frons transversely striated just above the antennal socket and longitudinal Striated between the antennal socket (frons coarsely punctate with a mid-longitudinal carina) (v). Carapace completely black (carapace black except basal yellow band) (vi). Prescutellar furrow broad with five mid longitudinal carinae (prescutellar furrow broad with three strong mid longitudinal carina) (vii). Ventral opening reaches more than half of the metasoma (ventral opening reaches almost upto the middle of the abdomen).

\section{Description}

Female: Body length: $2.5 \mathrm{~mm}$; Length of fore wing: $1.7 \mathrm{~mm}$; length of antenna: $1.7 \mathrm{~mm}$.

\section{Head}

ca2.8 $\times$ as wide as long in dorsal view; eye $2 \times$ as temple in dorsal view; OOL:POL: AOL : OD = 7:4:2:2: vertex and temple strigoso-punctate with hairs; frons smooth, just above the antennal socket transversely striated and between antennal socket having longitudinally striation; face almost $2 \times$ as wide as long, rugulose, clypeus punctate with hairs; malar space $2 \times$ basal width of mandible $(6: 3)$; antenna 18 segmented, distinctly shorter than body length, flagellomeres gradually decreasing in length towards apical; $\mathrm{F}_{14}-\mathrm{F}_{16}$ slightly longer than $\mathrm{F}_{13}$.

\section{Mesosoma}

$1.3 \times$ as long as its height; mesoscutum rugosoreticulate, notauli distinct by the presence of deeper reticulation along the notaular lines, mesonotum with a mid-longitudinal carina, prescutellar furrow broad with mid longitudinal carina and four lateral carina; scutellum rugoso-reticulate; metanotum with crenulated furrow; propodeum rugoso-reticulate; mesopleuron rugosoreticulate,

\section{Wings}

Fore wing slightly infuscate, $2.1 \times$ as long as wide; stigma almost $2 \times$ as long as wide $1-\mathrm{R} 1$ slightly longer than stigma; $r$ shorter than half the breadth of stigma, $r: 3-S R$ : SR1 $=5: 3: 17$, fore wing shorter than body length.

Legs

Hind coxa smooth and hairy; almost $2 \times$ as wide as long, length of femur, tibia, and basitarsus of hind leg $2.3 \times$ $3.57 \times$ and $2.3 \times$ their width, respectively. 


\section{Metasoma}

Metasoma $1.72 \times$ as long as wide; Metasoma slightly longer than mesosoma; carapace rugoso-reticulate with two strong longitudinal carina at basal one-fourth part of the metasoma; ventral opening reaches more than half of the metasoma; ovipositor short hardly visible laterally.

\section{Colour}

Body black except for the following: antenna, tegulae, all femora and apex of tibia, ovipositor, veins (except $\mathrm{M}+\mathrm{CU}$ ) light brown; stigma, $\mathrm{M}+\mathrm{CU}$ dark brown, all tarsus and tibial spurs yellow.

Male

\section{Unknown}

Host

Acrocercops caerulea (Meyrick)

\section{Distribution}

India: Uttar Pradesh

\section{Etymology}

The species name is derived from the name of the host species.

\section{Chelonus (Areselonus) chailini (Walker and Huddleston)}

Chelonus chailini Walker and Huddleston, 1987: 437-440. ㅇ. Malasia, (BMNH).

\section{Material examined}

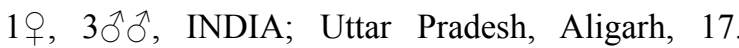
viii.2006, ex. Acrocercops phaeospora Meyrick (coll. Kavita Pandey) (ZDAMU); 5우, 7ふえへ, INDIA; Uttar Pradesh, Bulandshahr, 11.viii.2012, ex. Acrocercops phaeospora Meyrick (coll. Zubair Ahmad) (ZDAMU).

\section{Hosts}

Acrocercops caerulea Meyrick, A. Diffluella van Deventer, A. globulifera Meyrick, Epicephala chalybacma Meyrick. A. phaeospora Meyrick recorded doubtfully from India by Walker and Huddleston, 1987, A. phaeospora (present record)

\section{Distribution} Guinea.

China; Malaysia; India (Uttar Pradesh); Papua New

\section{Chelonus (Areselonus) lithocolletiscus Ahmad and Pandey, sp. nov.}

(Fig. 2)

\section{Material examined}

Holotype: +, India: Uttar Pradesh; Aligarh, 28 VII 2005, ex. Lithocolletis virgulata on and Pongamia

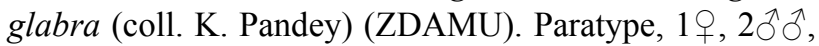
with same data as holotype (ZDAMU). Paratype, $4 \circ 9$, 1ठ̄, India: Uttar Pradesh; Aligarh, 11 VIII 2007, ex. Lithocolletis virgulata on Terminalia bellerica (coll. Z. Ahmad).
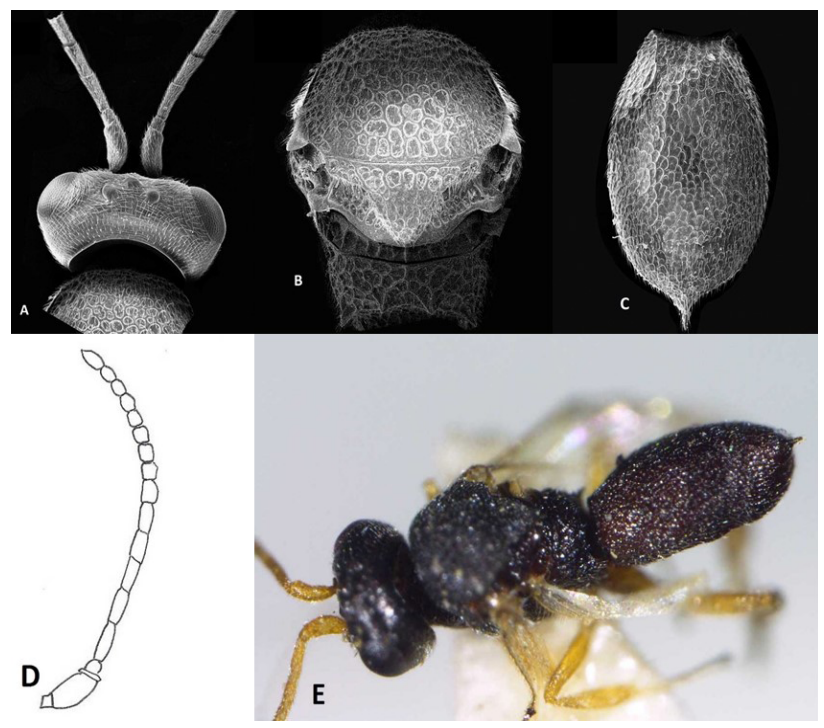

Fig. 2. Chelonus (Areselonus) lithocolletiscus, sp. nov., female, holotype; A, Head dorsal view; B, Mesosoma dorsal view; C, Metasoma dorsal view; D, Female antenna; E, Body profile dorso-lateral view.

\section{Diagnosis}

C. (A.) lithocolletiscus sp. nov., closely related to $C$. (A.) chailini (Walker and Huddleston) but differs in the following characters: (i). Mesoscutum punctate reticulate (mesoscutum reticulate rugose) (ii). Propodeum reticulate (propodeum reticulate rugose) (iii). 3-SR as long as r, (3SR $1.3 \times$ as long as r) (iv). Scape $2 \times$ as long as wide (scape $2.3 \times$ as long as wide). The new species also differs from other known Indian species viz., $C$. (A.) spinigaster Ahmad and Gharamh by metasoma not declivous but making an angle with the spine (Metasoma strongly declivous below the spine); clypeus punctate (clypeus rugose).

\section{Description}

Female: Body length: $2.42 \mathrm{~mm}$; Length of fore wing: $1.87 \mathrm{~mm}$; Length of antennae: $1.67 \mathrm{~mm}$.

Head

$2.5 \times$ as wide as long; eyes almost $2 \times$ temple; frons concave area smooth, medially convex punctate and at 
sides longitudinally striated; OOL: POL: $\mathrm{AOL}: \mathrm{OD}=6.5$ : 3: 2; vertex and temple pubescent, striated; face strigose, almost $2 \times$ as wide as long, only at the margin of eyes with longitudinally striated; clypeus wide almost $2 \times$ as wide as long, punctate with hairs; malar space $1.5 \times$ basal width of mandible; scape $2 \times$ as long as wide; antennae 16 segmented, flagellomeres gradually decreasing in length apically.

\section{Mesosoma}

$1.42 \times$ as long its height; mesoscutum, punctate reticutate, notauli finely impressed; scutellum punctate reticulate; propodeum $2.0 \times$ as wide as long reticulate with a short median longitudinal carina present; metanotum with longitudinal carina.

\section{Wings}

Stigma $2.5 \times$ as long as wide; $1.1 \times 1-\mathrm{R} 1,3$-SR as long as r; SR1slightly curved.

Legs

Length of femur, tibia and basitarsus of hind legs 3.5, 4.0 and $4.0 \times$ their maximum width.

\section{Metasoma}

Metasoma convex, reticulate, converging carina on basal fourth and a spine at apex; in lateral view $3.3 \times$ as long as hight (40:12); ovipositor sheath $1.2 \times$ longer than hind basitarsus hairy; ovipositor pointed, ventral opening reacting at the apex.

\section{Colour}

Body brownish black; antennae yellow gradually becoming yellowish brown towards apex; eyes greyish; ocelli brown; legs yellow; hind femur and apex of hind tibia yellowish brown; coxae red testaceous, wings hyaline; stigma $\mathrm{C}+\mathrm{SC}+\mathrm{R}$ and 1-R1 brown, rest of the vein pale.

Male

Same as holotype:

\section{Host}

Lithocolletis virgulata on Pongamia glabra and Terminalia bellerica.

\section{Distribution}

India: Uttar Pradesh

\section{Etymology}

The species name refers to the generic name of the host plant.

\section{CONCLUSION}

The Indian subcontinent has one of the unique biodiversity rich region of the world because of its varied climatic and geographical features. It occupies almost 4.4 million $\mathrm{km} 2$ area and considered as the confluence point of three biographic realms viz., the palearctic, afro-tropical and Indo-Malayan. This unique bio ecoregion exhibits a great variety of ecological habitats which harbors rich faunal and floral diversity and provide ample scope to sustain numerous species of insects and host plants. However, the greater part of this region is unexplored. More exploration in future will provide further knowledge of the faunal wealth of this region. Our findings of two new species reared from the leafmining lepidopteran larvae from the trees near the agrarian ecosystem provide important evidence that the wild area, as well as agrarian ecosystem could have more species fauna in the surrounding territories.

\section{ACKNOWLEDGEMENTS}

ZA extends his gratitude to the Research Center for Advanced Materials Science (RCAMS), King Khalid University for funding through research program (RCAMS)-04/20.

\section{Statement of conflict of interest}

The authors have declared no conflict of interest.

\section{REFERENCES}

Ahmad, Z., Gharamh, H.A. and Ali, A. 2017. A preliminary survey of Hymenopteran parasitoids associated with mango leafminer Acrocercops syngremma (Meyrick) [Lepidoptera: Gracillariidae] from India. Asian J. Agric. Life Sci., 2: 43-44.

Ahmad, Z. and Gharamh, H.A., 2018. A new species of Chelonus (Areselonus) (Hymenoptera, Braconidae) from India reared from Acrocercops lysibathra (Meyrick) on Cordia latifolia Roxb. Zoo. Keys, 737: 75- 80. https://doi.org/10.3897/zookeys.737.20835

Bellows, T.S. and Fisher, T.W., 1999. Handbook of biological control: principles and applications of biological control (No. 632.96 B4). Academic Press.

Braet, Y., 1999. Description of new Braconidae (Hymenoptera) from Papua New Guinea. Belg. J. Ent., 1: 3-20.

Chatterjee, P.N. and Misra, M.P., 1974. Natural insect enemy and plant host complex of forest insect pests of Indian Region. Ind. For. Bull., 265: 1- 233. 
Csoka, G., 2003. Levélaknák és levélaknázók [Leaf mines and leaf miners]. Agro in form Kiadóés Nyomda, Budapest. pp.192 (in Hungarian).

Davis, D.R., 1987. Gracillariidae. In: Immature insects (ed. F.W. Stehr). Vol. 1, Dubuque, Kendall/Hunt publishing Company. pp. 372-374, 755.

Eady, R.D., 1968. Some illustrations of microsculpture in the Hymenoptera. Proc. R. Ent. Soc. Lond. (A)., 43: 66-72. https://doi.org/10.1111/j.1365-3032.1968. tb01029.x

Gates, M.W., Heraty, J.M., Schauff, M.E., Wagner, D.L., Whitfield, J.B., and Wahl, D.B., 2002. Survey of the parasitic Hymenoptera on leafminers in California. J. Hymen. Res., 11: 213-270.

Hawkins, B.A., Thomas, M., and Hochberg, M.E., 1993. Refuge theory and classical biological control. Science, 262: 1429-1432. https://doi.org/10.1126/ science.262.5138.1429

Huddleston, T., and Walker, A.K., 1994. A revision of Chelonus scrobiculatus species-group of Chelonina (Insecta: Hymenoptera: Braconidae). Ann. Nat. Hist. Mus. Wien., 96: 153-168.

Kittel, R.N., and Austin, A.D., 2014. Synopsis of Australian chelonine wasps (Hymenoptera: Braconidae: Cheloninae) with description of two new genera. Aust. Ent., 53: 183-202. https://doi. org/10.1111/aen. 12070

Kittel, R.N. Austin, A.D. and Seraina, K., 2016. Molecular and morphological phylogenetics of chelonine parasitoid wasps (Hymenoptera: Braconidae), with a critical assessment of divergence time estimations. Mol. Phylogen. Evol., 101: 224-241. https://doi.org/10.1016/j. ympev.2016.05.016

Long, K.D., Van Duong, N. and Hoa, D.T., 2019. New records of rare genera of the subfamily Cheloninae (Hymenoptera: Braconidae), with description of two new species from Vietnam. Acad. J. Biol.,
41: 1-9. http://doi.org/10.15625/2615-9023/ v41n3.13884

Narendran, T.C., Sumodan, P.K. and Rema, C.G., 1992. A study of Indian species of Chelonus Panzer (Hymenoptera: Braconidae). J. Zool. Soc. Kerala, 2: 1-9.

Nixon, G.E.J., 1940. New genera and species of Hormiinae, with a note on Hormiopterus Giraud (Hymenoptera, Braconidae). Annls Mag. natl. Hist., 5: 473- 492. https://doi. org/10.1080/00222934008527064

Shaw, M.R. and Huddleston, T., 1991. Classification and biology of braconid wasps (Hymenoptera: Braconidae). Handbk. Ident. Br. Insects, 7: 3-126.

Shujauddin and Varshney, K., 1997. A new species of the genus Ascogaster Wesmeal (Hymenoptera: Braconidae) from India. Shashpa, 4: 95-97.

Spencer, K.A., 1990. Host specialization in the world Agromyzidae (Diptera). Kluwer Academic Publishers, Dordrecht, pp. 444. https://doi. org/10.1007/978-94-009-1874-0

van Achterberg, C., 1993. Illustrated key to the subfamilies of the Braconidae (Hymenoptera: Ichneumonoidea). Zool. Verh. Leiden, 83: 1-189.

Walker, A.K. and Huddleston, T., 1987. Chelonus chailini sp. n. (Hymenoptera: Braconidae) from Malaysia, parasitizing gracillariid moth (Lepidoptera). Bull. Ent. Res., 77: 437-440. https:// doi.org/10.1017/S0007485300011913

Wilkinson, D.S., 1928. A revision of the IndoAustralian species of the Apantales (Hymenoptera: Braconidae) Part II. Bull. Ent. Res., 19: 102-146. https://doi.org/10.1017/S0007485300020393

Yu, D.S. van Achterberg, C. and Horstmann, K., 2012. Ichneumonoidea 2011 (Biological and taxonomical information): Taxapad Interactive Catalogue, Ottawa. Retrieved from www.taxapad.com. 